\title{
Is There Any Prognostic Relationship Between Malignant Peripheral Nerve Sheath Tumors And NF Type 1?
}

\section{Malign Periferik Sinir Kılıfı Tümörlerinin NF Tip 1 ile Prognostik İlişkisi Var midır?}

\author{
Coskun Ulucakoy, Aliekber Yapar, Recep Öztürk, Güray Toğral, Bedii Şafak Güngör \\ Ankara Onkoloji Eğitim ve Araştırma Hastanesi
}

Dergiye Ulaşma Tarihi: 27.06.2019 Dergiye Kabul Tarihi:05.08.2019 Doi: 10.5505/aot.2020.44154

\begin{abstract}
ÖZET
GíRiş ve AMAÇ: Bu çalışmada nadir görülen yumuşak doku sarkomlarından olan malign periferik sinir kıllfı tümörlerinin (MPSKT) klinik özelliklerini ve Nörofibromatozis tip 1 (NF1) ile prognostik ilişkisini araştırmayı amaçladık.

YÖNTEM ve GEREÇLER: Ocak 2002 ve Aralık 2015 tarihleri arasında MPSKT nedeniyle opere edilen 42 (26 E, $16 \mathrm{~K}$ ) hastanın klinik özellikleri, tedavi yöntemleri, klinik sonuçları ve tedavi başarısızlıkları retrospektif

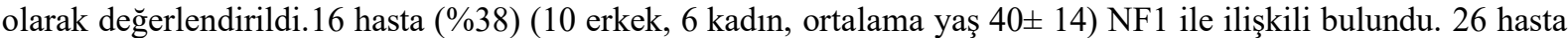

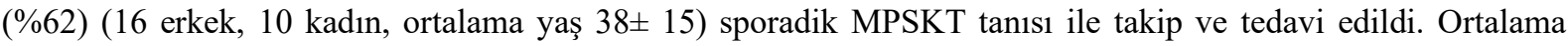
takip süresi NF1 ile ilişkili grupta 30 ay $( \pm 12)$ ve sporadik MPSKT grubunda 42 ay $( \pm 15)$ idi. En ssk yerleşim yeri ekstremite $(\% 85)$ ve ortalama tümör boyutu $11,2 \mathrm{~cm}$ (dağılım $2-21 \mathrm{~cm})$ idi. Tüm hastalara tanı sonrası geniş rezeksiyon uyguland1.

BULGULAR: İki grup arasında tümör boyutu, tümör yerleşimi ve lenf nodu tutulumu ve uzak organ metastazı açısından anlamlı fark yoktu.Tüm hastalarda makroskopik cerrahi sınır negatif iken,NF1 ile ilişkili grupta 5 hastada(\% 31) ve sporadik grupta 9 hastada(\% 34) mikroskobik cerrahi sinır pozitif (R1) olarak rapor edildi. 42 hastanın 20'sinde (\% 47) nüks görüldü. NF1 ilişkili grupta 13 hastada (\% 81), sporadik grupta 7 hastada(\% 26) nüks görüldü. Mikroskobik cerrahi sınır pozitif olan hastalarda mortalitenin 11,4 kat artığı gözlenmiştir. TARTIŞMA ve SONUÇ: NF1 zemininde gelişen malign periferik sinir kıllfı tümörlerinde prognoz sporadik tipe göre daha kötüdür. Ayrıca tümörün boyutu, derinliği, pozitif cerrahi sınır kötü prognoz göstergeleridir. Sağkalımı etkileyen en önemli faktör NF1 varlığı ve pozitif cerrahi sınırdır.
\end{abstract}

Anahtar Kelimeler: Malign periferik sinir kılıfı tümörü, Nörofibromatozis tip 1, Prognoz, Tedavi sonuçları

ABSTRACT
INTRODUCTION: In this study, we aimed to research the clinical features of malignant peripheral nerve sheath tumors (MPNST) which are rare soft tissue sarcomas and their prognostic relationship with Neurofibromatosis type 1 (NF1).

METHODS: The clinical features, treatment modalities, clinical outcomes and treatment failures of 42 (26 males, 16 females) patients operated for MPNST between January 2002 and December 2015 were evaluated retrospectively. 16 patients (38\%) (10 males, 6 females, mean age $40 \pm 14)$ were associated with NF1. 26 patients (62\%) (16 males, 10 females, mean age $38 \pm 15)$ were treated and followed up with sporadic MPNST diagnosis. The mean follow-up period was 30 months $( \pm 12)$ in the NF1-associated group and 42 months $( \pm 15)$ in the sporadic MPNST group. The most common site was extremity (85\%) and mean tumor size was $11.2 \mathrm{~cm}$ (range between 2 and $21 \mathrm{cms}$ ). All patients underwent wide resection after diagnosis.

RESULTS: There was no significant difference between the two groups in terms of tumor size, tumor location, lymph node involvement and distant metastasis. In all patients, macroscopic surgery margin was negative, while 5 patients (31\%) in the NF1-associated group and 9 patients (34\%) in the sporadic group the margin was reported as positive (R1). Recurrence was seen in 20 of 42 patients (47\%). Recurrence was seen in 13 patients $(81 \%)$ in the NF1-associated group and 7 patients (26\%) in the sporadic group. Mortality rate increased by 11.4 times in patients with positive microscopic surgical margin.

DISCUSSION AND CONCLUSION: The prognosis of malignant peripheral nerve sheath tumors developing on NF1 background is worse than sporadic type. In addition, tumor size, tumor depth and positive surgical margin are indicators of poor prognosis. The most important factor affecting survival is the presence of NF1 and the positive surgical margin.

Adress for correspondence: Uzm. Dr. Coskun Ulucakoy, Ankara Onkoloji Hastanesi Demetevler Ankara - Türkiye

Copyright $($ Ankara Onkoloji Hastanesi 
Keywords: Malignant Peripheral Nerve Sheath Tumors, Neurofibromatosis type 1, Prognosis, Surgical treatment outcome

\section{Gİiș}

Periferik sinir kılıfı tümörleri schwann hücreleri, perinöral hücreler ve nöralfibroblastlardan gelişir. Schwann hücrelerinden gelişenler schwannom adını alır. Schwann hücreleri ile fibroblastlardan gelişenler nörofibrom adını alır. Perinöral hücrelerden gelişenler de perinöroma adını alır (1).

Malign periferik sinir kılıfı tümörleri (MPSKT) daha çok schwann hücrelerinden kaynaklanan nadir görülen yumuşak doku sarkomlarındandır. Görülme sıklığı 1/ 100000 'dir.Çoğunlukla periferik sinir kılıfi tümörlerinden soliternörofibrom ya da pleksiformnörofibrom üzerinde gelişir. MPSKT tümörlerinin \%60'1nda nörofibrom komponenti gösterilmiştir. MPSKT tanımı içerisine; malign schwannoma, nörojenik sarkom, nörofibrosarkom ve anaplastiknörofibrom girer (2).

Nörofibromatozis tip 1 (NF1) ile ilişkili ya da sporadik tek başlarına olabilirler. NF1,MPSKT 'lerine göre daha s1k görülen bir sendromdur. Görülme sıklığ 1/3000 'dir. Genetik olarak kromozom 17q11.2 'de yerleşen ve nörofibromin proteinini kodlayan NF1 geninde mutasyona bağlı oluşur. Hastalık multipl nörofibromlar, karakteristik kemik displazileri, iriste pigmente Lisch nodülleri,optik sinir gliomları ve ciltte hiperpigmente maküler lekeler ile karakterizedir $(3,4)$. NF1; etkilenen bireylerin MPSKT 'üne yatkınlığını arttıran otozomal dominant kalıtımlı bir sendromdur. Kötü prognozludur ve multidisipliner bir yaklaşım gerektirir (5). NF1 tanılı bireylerde mevcut nörofibromlardan MPSKT gelişme riski \% 10 'dur. Genellikle uzak organ metastazları mevcut olup NF1 hastalarının sıklıkla ölüm nedenidirler (6). Lokal nüksskılıkla görülür. Perinöral hücre farklılaşması olanlar hariç
MPSK tümörleri çok agresif tümörlerdir ve NF1 hastalarının \%60'1 MPSKT sebepli ölmektedir (7).

MPSKT daha çok yetişkinlerde görülür ve yaşamın ilk iki yılında sadece \% 10 ila 20'si teşhis edilir. Yine de pediatrik çağda en sık rastlanan nonrabdomyosarkomatöz yumuşak doku sarkomlarından birini temsil eder (8).

MPSKT büyük sinir traktusleri üzerinde lokalize olur, en sık ekstremiteler ve gövde sinirlerinin proksimalinde oturur, daha az olarak baş-boyun bölgesinde yer alır. Kranial sinirlerde MPSKT nadirdir. Multifokal MPSKT de çok çok azdır. NF1 olgularındaki MPSKT santral lokalize olur ve daha kötü prognoz gösterir (9).

MPSKT makroskopik olarak sıklıkla 5 $\mathrm{cm}$ den büyük kitle, büyük sinirler üzerinde füziform ya da eksantrik yerleşimli kitle biçimindedir. Kesitinde kanama ve nekroz alanları görülür. Mikroskopik olarak ise yoğun iğsi hücrelerden oluşan sellüler fasiküller, storiform görünüm yapar. Perivaskuler ve subendotelial tümör hücre inflitrasyonu tipiktir (1).

MPSKT nadir görülmesi sebebiyle literatürde yeterli yayın mevcut değildir. Prognozu etkileyen faktörler, cerrahi , kemoterapi ve radyoterapinin sağkalım üzerine etkileri hala tartışılmaktadır. Tedavinin temelini negatif cerrahi sinır ile rezeksiyon oluşturmaktadır. Lokal kontrolü sağlayamamak tedavi başarısızlığının en önemli nedenidir. Güncel tüm tedavilere rağmen MPSKT sonrası 5 yıllık sağkalım \% 35 ile \% 50 arasında değişmektedir (10).

\section{GEREÇ ve YÖNTEM}

Ocak 2002 ile aralık 2015 yılları arasında kliniğimizde MPSKT tanısıyla ameliyat edilen hastalar retrospektif olarak tarand1. NF1 ile 
ilişkili 16 (\% 38) hasta (10 E, $6 \mathrm{~K})$ ve sporadik 26 (\% 62) hasta (16 E, $10 \mathrm{~K})$ tanı yaş1, cinsiyet, boy, kilo, VKİ, NF1 varlığ1, ağr1, boyut, lokalizasyon, derinlik, takip süresi, evre ve nüks durumlarına göre değerlendirildi.

\section{İstatistiksel Analiz}

Araştırma verilerinin istatistiksel analizleri için Statistical PackageforSocialSciences22.0 (SPSS Inc. Chicago, USA) program 1 kullanılmıştır. Tanımlayıcı istatistikler kısmında kategorik değişkenler sayı, yüzde verilerek, sürekli değişkenler ise ortalama \pm standart sapma ve ortanca (en küçük- en büyük değer) ile sunulmuştur. Sürekli değişkenlerin normal dağılıma uygunluğu görsel (histogram ve olasillk grafikleri) ve analitik yöntemler (Kolmogorov-Smirnov/Shapiro-Wilk testleri) kullanılarak değerlendirilmiştir. Normal dağılıma uymayan verilerde, iki grup arasındaki karşılaştırma analizleri için MannWhitney U testi, normal dağılım gösterenlerde ise IndependentSamples $\mathrm{T}$ testi kullanılmıştır. Bağımsız gruplar arasında kategorik değişkenler için yapılan karşılaştırma analizlerinde ki-kare testi kullanılmıştır.

Sağkalım $\begin{gathered}\text { hızları } \\ \text { analizi }\end{gathered} \begin{gathered}\text { Kaplan- } \\ \text { kullanılarak }\end{gathered}$
Meiersağkalım hesaplanmıştır. Gen mutasyonuna göre
grupların sağkalım süresi log-rank testi
kullanılarak incelenmiştir. Sağkalım süreleri
medyan sağkalım süresi, standart hata ve \%95
güven aralığ ile sunulmuştur. NF-1 gen
mutasyonunun ve diğer faktörlerin mortalite
üzerine etkisi Multivariate Cox regresyon
analizi ile incelenmiştir. Cox regresyon analizi
ile kurulan modelde düzeltilmiş HazardRatio
(adjusted HR) hesaplanmıştır. Bu çalışmada
istatistik anlamlılık düzeyi $\leq 0,05$ olarak kabul
edilmiştir.

\section{BULGULAR}

Bu çalışmaya 26'sı erkek 16'sı kadın ortalama tan1 yaş1 39,3 (min:22,0-mak:77) olan 42 MPSKT tanısı olan hasta dâhil edilmiştir.
Hastalar ortalama 37,7 (min:12,0-mak:68,0) ay takip edilmiştir. Hastaların ortalama VKİ 28,1 $(18,7-38,9) \quad$ bulunmuştur. Hastaların \%38,1'inde NF-1 gen mutasyonu saptanmıştır (Şekil 1). Tümörlerin 36's1 (\%85,7) ekstremite yerleşimli olup 32'si $(\% 76,2) 5 \mathrm{~cm}$ altında bulunmuştur. Sadece 2 hastada yüzeyel yerleşimli tümör saptanmıştır. Hastaların $\% 66,7^{\prime}$ 'si negatif cerrahi sinırlı kalanı $(n=14)$ ise mikroskobik pozitif cerrahi sinırlıdır. Hastaların 24'ünde $(\% 57,1)$ Lenf nodu metastaz1, 16'sinda $(\% 38,1)$ ise uzak organ metastazı saptanmıştır. Lenf nodu metastazı olan 24 hastanın ise \%66,7 ( $\mathrm{n}=16)$ 'sinde uzak organ metastazı olduğu gözlenmiştir. Lenf nodu metastazı olmayan hastaların hiç birinde uzak organ metastazı gözlenmemiştir. Nüks açısından değerlendirildiğinde takipte 20 $(\% 47,6)$ hastada nüks saptanmıştır (Tablo 1). Tüm hastalarda takip süresi sonunda exitus meydana gelmiştir.

Tablo 2'de NF-1 ilişkili ve Sporadik olmak üzere iki hasta grubunun bazı demografik ve klinik özelliklerinin değerlendirilmesi yapılmıştır. Her iki grup arasında tanı yaşı, VKİ değerleri, cinsiyet, lokalizasyon, boyut, yerleşim, cerrahi sınır, lenf nodu metastazı ve uzak organ metastazı açısından istatistiksel olarak anlamlı bir farklı1ık saptanmamıştır ( $>00,05)$.NF-1 İlişkili grubun takip süresi istatistiksel olarak anlamlı düzeyde daha kısa bulunmuştur ( $p=0,021)$. NF1 ilişkili grubun \%81,3'ünde, Sporadik grubun ise \%26,9'unda nüks gözlenmiştir. NF-1 ilişkili grupta istatistiksel olarak anlamlı düzeyde daha fazla nüks olduğu gözlenmiştir $(\mathrm{p}=0,001)$.

\section{Sağkalım Analizi}

$\mathrm{Bu}$ çalışmada 42 hastanın tamamında takip süreleri sonunda exitus meydana geldiği görülmüştür. Hastaların medyan sağkalım

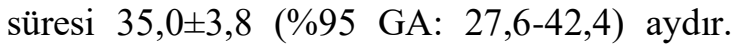
Bir yıllık sağkalım hızı \%97,6, 3 yıllık sağkalım hızı \%47,6 ve 5 yıllık sağkalım hızı $\% 16,7$ bulunmuştur. Gen Mutasyonuna göre 
hastaların sağkalım süreleri karşılaştırıldığında; NF-1 ilişkili hastalarda medyan sağkalım sürelerinin Sporadik hastalara göre istatistiksel olarak anlamlı düzeyde daha kısa daha olduğu saptanmıştır (LogRank test; $\mathrm{p}=0,014$ ) (Tablo 3). NF-1 ilişkili hastalarda 3 yıllık sağkalım hızı \%31,3 Sporadik olanlarda ise \% 57,7 bulunmuştur (Şekil 2). Cerrahi sınır pozitif hastalarda medyan sağkalım sürelerinin negatif hastalara göre istatistiksel olarak anlamlı düzeyde daha kısa daha olduğu saptanmıştır (Log Rank test; $\mathrm{p}<0,001$ ) (Şekil 3). Hastaların medyan sağkalım süreleri ve sağkalım hızları Tablo 3 'de sunulmuştur. Hastaların mortalite riskleri Univariate ve multivariate Cox regresyon analizi ile değerlendirilmiştir. Yapılan Univariate Cox regresyon analizinde $p<0,05$ bulunan faktörler (cerrahi sinır, gen mutasyonu, tanı yaşı, nüks durumu ve lenf nodu metastazi) multivariate Cox regresyon analizine dâhil edilmiştir. Regresyon modeli incelendiğine Mikroskobik cerrahi sınır pozitif olan hastaların $(\mathrm{HR}=11,4 ; \% 95 \mathrm{GA}=4,3-29,9$; $\mathrm{P}<0,001)$, NF-1 ilişkili olan hastaların (HR=3,7; \%95 $\mathrm{GA}=1,4-9,4 ; \mathrm{P}=0,007)$, tan1 yaş1 büyük olan hastaların $(\mathrm{HR}=1,04 ; \% 95$ $\mathrm{GA}=1,01-1,08 ; \mathrm{P}=0,003)$, lenf nodu metastaz1 pozitif olan hastaların $(\mathrm{HR}=4,5 ; \% 95 \mathrm{GA}=1,8$ 11,4; $\mathrm{P}=0,001)$ ve nüks olan hastaların $(\mathrm{HR}=2,6 ; \quad \% 95 \quad \mathrm{GA}=1,1-6,3 ; \quad \mathrm{P}<0,001)$ mortalite riskinin fazla olduğu tespit edilmiştir. $\mathrm{Bu}$ çalışmada mortalite üzerine en etkili olan faktörün mikroskobik cerrahi sınır oluğu gözlenmiştir, Mikroskobik cerrahi sınır pozitif olan hastalarda mortalitenin 11,4 kat artığ gözlenmiştir.

\section{TARTIŞMA}

Malign periferik sinir kılıfı tümörleri tüm yumuşak doku tümörlerinin \%5-10 udur, Ülkemizde yakın zamanda yapılan bir çalışmada \% 6,7 olarak bulunmuştur $(11,12)$. MPSKT en sık 35-44 yaş arası olmak üzere sıklıkla erişkinlerde görülmekle beraber çocuklarda da görülebilir $(11,13,14)$. Bizim çalışmamızda da yaş ortalaması 39,3 idi ve hiçbir çocuk yaşta hastamız yoktu, ancak geniş bir yaş aralığında hastalarda görüldü, en küçük hastamız 22 yaşında iken en yaşlı hastamız 77 yaşında idi. .

MPSKT nin nörofibromatozisle ilişkisi bilinmektedir, hatta bazı çalışmalarda vakaların yaklaşık yarısının NF tip 1 ile ilişkili olduğu bildirilmektedir $(11,13,14)$. Bizim çalışmamızda da vakaların \%38'i NF1 ile ilişkili idi.

NF1 ilişkili grubun sporadik gruba göre prognozunun ve sağkalımının daha kötü olduğunu bildiren yayınlar mevcuttur $(10,13,15,16)$. Kohlberg ve ark. 1800den fazla MPSKT nin sonuçlarını yayınladıkları çalışmada, NF1 ilişkili vakaların daha kötü prognozlu olduklarını bildirdiler (17). Bizim çalışmamızda da NF1 ilişkili vakalarda prognoz daha kötü olarak bulundu. NF-1 ilişkili hastalarda 3 yıllık sağkalım hızı \%31,3 Sporadik olanlarda ise $\% 57,7$ bulunmuştur.

MPSKT 'nin nadir görülen bir tümör olması ve tanı güçlüğü nedeniyle literatürde sınırlı sayıda veri mevcuttur. Bizim çalışmamız da yaklaşık 14 yıllık verileri içeriyordu ve sadece 42 hasta elde edildi.

MPSKT sıklıkla derin yerleşimli tümörlerdir. Hwang ve arkadaşları da 95 hastanın \% 88 'inin (84 hasta) derin yerleşimli olduğunu raporladılar (15). Bizim çalışmamıza dahil edilen 42 hastanın 36's1 (\%85,7) ekstremite yerleşimli olup sadece 2 hastada yüzeyel yerleşimli tümör saptanmıştır. 40 hasta (\% 95) derin yerleşimlidir.

$\mathrm{Bu}$ tümörün ayırıc1 tanısinda, leimyosarkom, liposarkom, haemangioma gibi benign veya malign yumuşak doku tümörleri bulunur (12,18-20). Bizim çalışmamızda da tüm lezyonlar, preoperatif olarak geniş bir yelpazede ön tanılar ile değerlendirildi, histopatolojik inceleme sonucu MPSKT gelmiş olan hastalar çalışmaya dahil edildi.

Carli ve arkadaşları 2005 yılında NF1 ilişkili grup ve sporadik gruptaki lenf nodu metastaz ve uzak organ metastazlarının benzer 
olduğunu söylediler (10). Bizim çalışmamızda da NF1 ilişkili olan ve olmayan grup arasında lenf nodu metastazı ve uzak organ metastazı açısından istatiksel olarak anlamlı bir fark yoktur.

Stucky ve arkadaşları 2013 yılında yayınladıkları Mayo klinik deneyimlerinde opere ettikleri 143 hastanın \% 37'sinde (55) nüks gözlemlediler. NF1 ilişkili grupta nüksün anlamlı olarak yüksek olduğunu bildirdiler (13). Bizim çalışmamızda NF-1 ilişkili grubun $\%$ 81,3'ünde, Sporadik grubun ise \% 26,9'unda nüks gözlenmiştir.

Yüksek grade yumuşak doku sarkomlarında geniş rezeksiyon yapılırken cerrahi sınır, kitle sınırlarının 3' $\mathrm{cm}$ ilerisinden yapılan sinırdır. Major damar sinir yapılar, geniş sinırlarla rezeksiyon yapmaya izin vermiyorsa, ya damarlar, sinirler de rezeke edilerek greft yerleştirilir ya da radioterapi ve kemoterapi gibi tedaviler açısından hasta değerlendirilir. Her hastaya ne yapılacağ 1 konusunda multidisipliner bir yaklaşım gereklidir (12). Bizim çalışmamızda 9 hastada cerrahi sinırlar pozitifti.

Sonuç olarak MPSK tümörü multidisipliner yaklaşım gerektiren agresif bir yumuşak doku sarkomudur. NF1 ilişkili MPSK tümörlerinin iyi yönetilmesi gerekmektedir. Sağkalımı etkileyen en önemli faktörler NF1 varlığ 1 ve pozitif cerrahi sınırdır.

\section{Çıkar Çatışması: Yok}

Tablo 1: Bazı Demografik ve Klinik Özellikler

\begin{tabular}{lc}
\hline Değişkenler $(\mathbf{n = 4 2})$ & \\
\hline Tanı Yaş, yıl & $39,3 \pm 14,9$ \\
Mean \pm ss & $33,0(22,0-$ \\
Medyan(min-maks) & $77,0)$ \\
& \\
\hline Cinsiyet, $\mathbf{n}(\boldsymbol{\%})^{*}$ & $26(61,9)$ \\
Erkek & $16(38,1)$ \\
Kadın & \\
\hline VKİ, kg/m & \\
Mean \pm ss & $28,1 \pm 3,9$ \\
Medyan(min-maks) & $27,9(18,7-$ \\
& $38,9)$ \\
\hline Gen mutasyonu, $\mathbf{n}(\boldsymbol{\%})$ & $26(61,9)$ \\
\hline ilişkili & $16(38,1)$ \\
\hline
\end{tabular}


Takip süresi, ay

Mean \pm SS

$37,7 \pm 15,4$

Medyan(min-maks)

$35,0(12,0-$

$68,0)$

\section{Lokalizasyon, n(\%)}

Ekstremite

$36(85,7)$

Gövde

$6(14,3)$

Boyut, n(\%)

$<5 \mathrm{~cm}$

$\geq 5 \mathrm{~cm}$

$10(23,8)$

Yerleşim, n(\%)

Derin yerleşimli

$40(95,2)$

Yüzeyel yerleşimli

2(4,8)

\section{Cerrahi sınır, n(\%)}

Negatif cerrahi sınır

$28(66,7)$

Mikroskobik pozitif cerrahi sınır

$14(33,3)$

\section{Lenf nodu metastazı}

Var

Yok

$18(42,9)$

\section{Uzak organ metastazı}

Var

$16(38,1)$

Yok

$26(61,9)$

\section{Nüks, n(\%)}

Var

Yok 
Tablo 2: Gen mutasyonu durumuna göre grupların karşılaştırılması

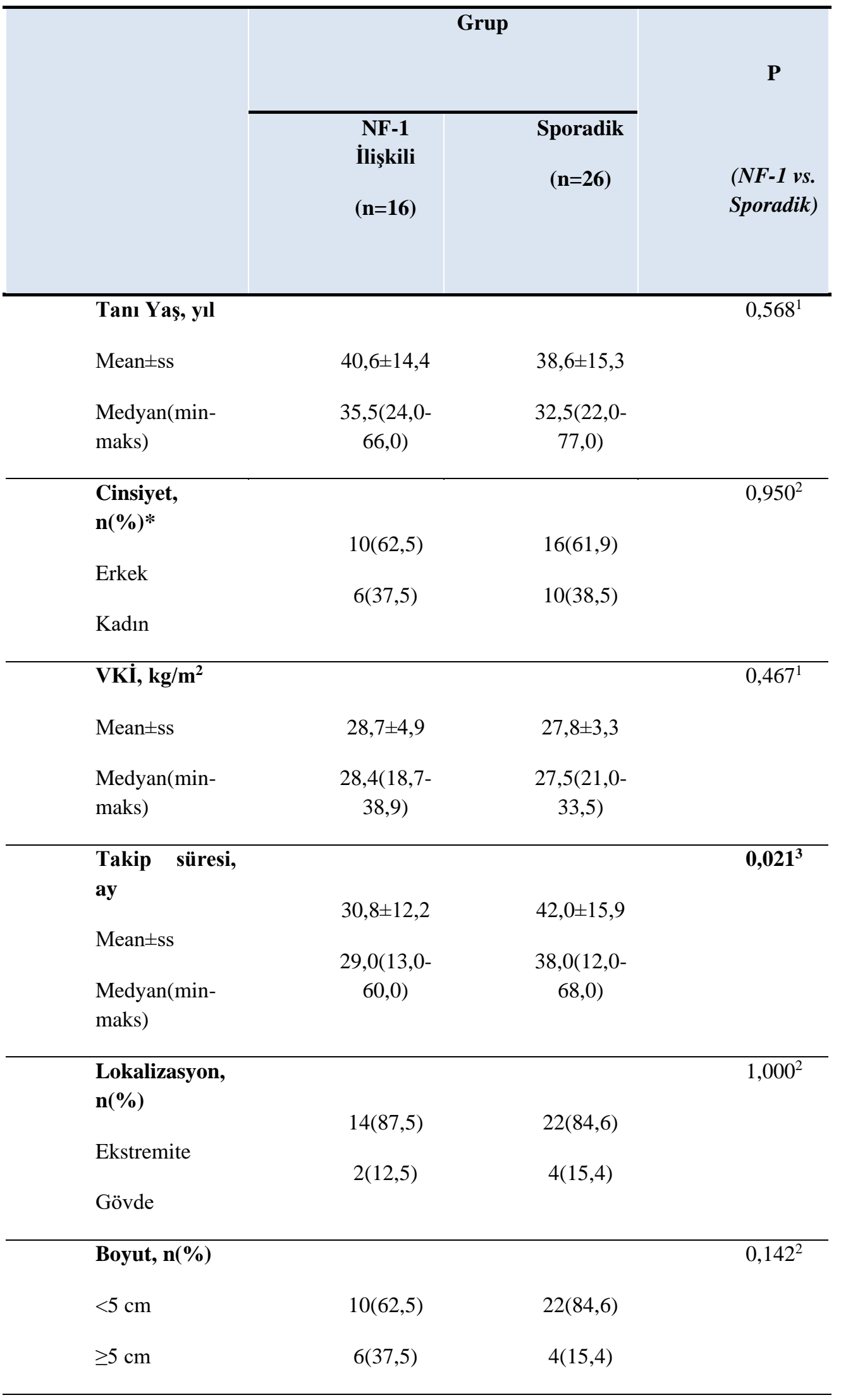


Yerleşim,

n(\%)

Derin

yerleşimli

$$
16(100,0)
$$

24(92,3)

Yüzeyel

yerleşimli

\begin{tabular}{lccc}
\hline $\begin{array}{l}\text { Cerrahi sınır, } \\
\text { n(\%) }\end{array}$ & $11(68,8)$ & $17(65,4)$ & $1,000^{2}$ \\
$\begin{array}{l}\text { Negatif cerrahi } \\
\text { sinır }\end{array}$ & $5(31,2)$ & $9(34,6)$ & \\
& & & \\
Mikroskobik \\
pozitif cerrahi \\
sinır
\end{tabular}


Tablo 3: Hastaların Sağkalım Süresi ve Hızları

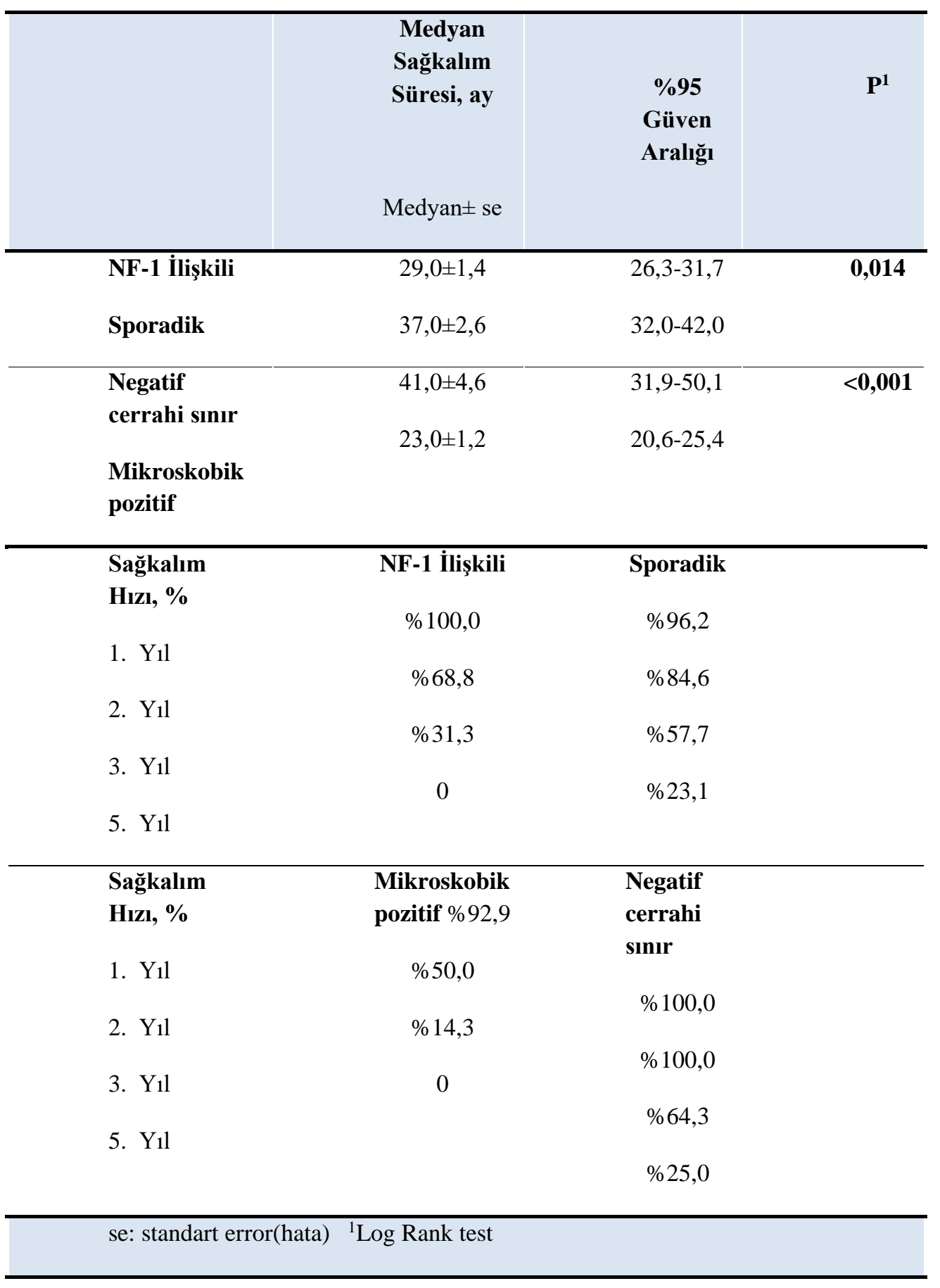




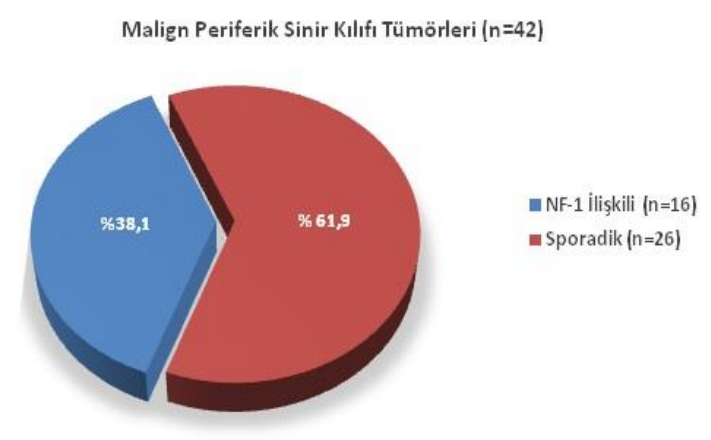

Şekil 1: Hastaların gen mutasyonuna göre dağılımı

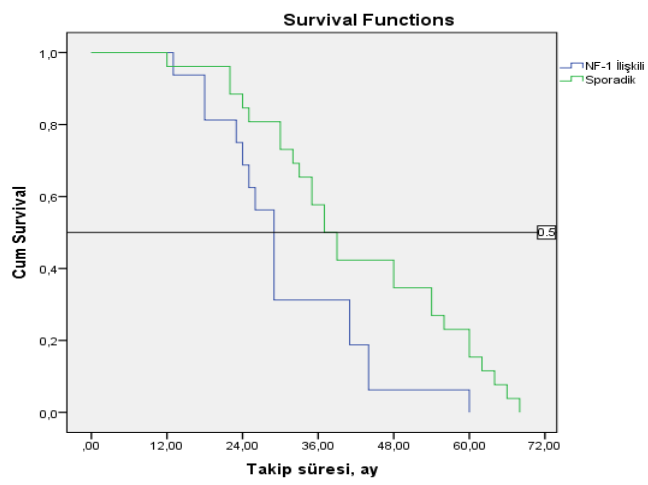

Şekil 2: Gen mutasyonuna göre hastaların KaplanMeier Sağkalım eğrileri

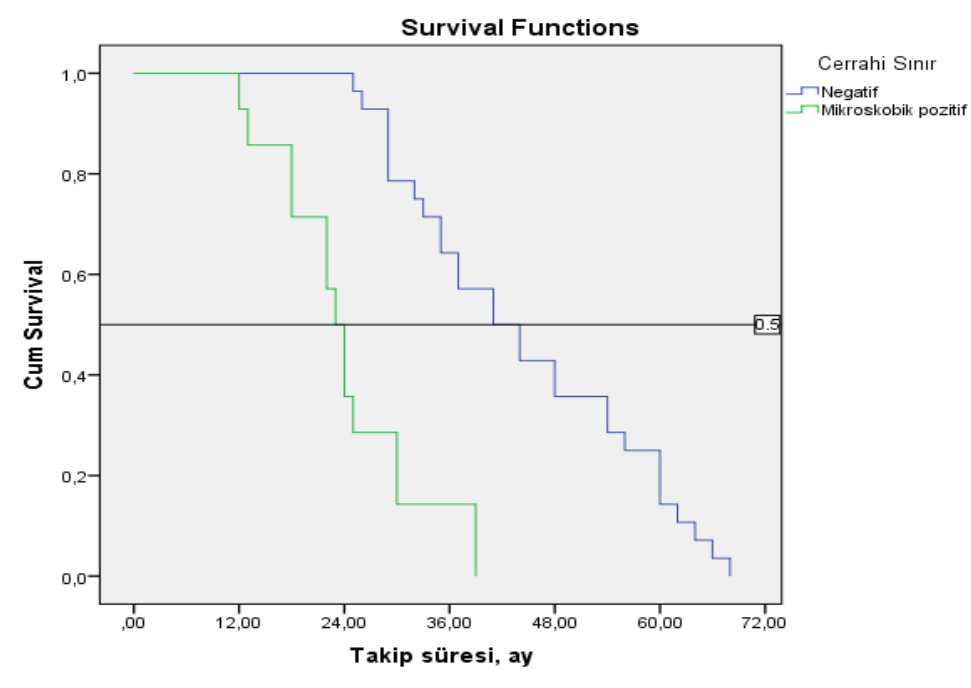

Şekil 3: Cerrahi sınıra göre hastaların Kaplan-Meier Sağkalım eğrileri

\section{REFERANSLAR}

1. Canda, M.Ş., Periferik sinir kılıfi tümörleri. Türkiye Ekopatoloji Dergisi, 2004. 10(1-2): p. 65-74.

2. Amirian, E.S., et al., Pediatric and adult malignant peripheral nerve sheath tumors: an analysis of data from the surveillance, epidemiology, and end results program. Journal of neuro-oncology, 2014. 116(3): p. 609-616.

3. Rasmussen, S.A. and J. Friedman, NF1 gene and neurofibromatosis 1. American journal of epidemiology, 2000. 151(1): p. 33-40.

4. Reynolds, R., et al., Von Recklinghausen's neurofibromatosis: neurofibromatosis type 1 . The lancet, 2003. 361(9368): p. 1552-1554.
5. Ferner, R.E. and D.H. Gutmann, International consensus statement on malignant peripheral nerve sheath tumors in neurofibromatosis 1. 2002, AACR.

6. Tucker, T., et al., Association between benign and malignant peripheral nerve sheath tumors in NF1. Neurology, 2005. 65(2): p. 205-211.

7. Varış, O., et al., Case Report: Malign Periferal Nerve Sheath Tumor.

8. Meis, J.M., et al., Malignant peripheral nerve sheath tumors (malignant schwannomas) in children. The American journal of surgical pathology, 1992. 16(7): p. 694-707.

9. Solomon, D., Consensus Development Panel. National Institutes of Health Consensus Development Conference statement: geriatric 
assessment methods for clinical decision-making. $\mathrm{J}$ Am Geriatr Soc, 1988. 36: p. 342-7.

10. Carli, M., et al., Pediatric malignant peripheral nerve sheath tumor: the Italian and German soft tissue sarcoma cooperative group. Journal of clinical oncology, 2005. 23(33): p. 8422-8430.

11. Vasconcelos, R. A. T. D., Coscarelli, P. G., Alvarenga, R. P., \& Acioly, M. A. (2017). Malignant peripheral nerve sheath tumor with and without neurofibromatosis type 1. Arquivos de neuro-psiquiatria, 75(6), 366-371.

12. Öztürk R, Arıkan ŞM, Bulut EK, Kekeç AF, Çelebi F, Güngör BŞ. Distribution and evaluation of bone and soft tissue tumors operated in a tertiary care center. Acta Orthop Traumatol Turc 2019; http://dx.doi.org/10.1016/j.aott.2019.03.008.

13. Stucky, C.-C.H., et al., Malignant peripheral nerve sheath tumors (MPNST): the Mayo Clinic experience. Annals of surgical oncology, 2012. 19(3): p. 878-885.

14. Zehou, O., et al., Chemotherapy for the treatment of malignant peripheral nerve sheath tumors in neurofibromatosis 1: a 10-year institutional review. Orphanet journal of rare diseases, 2013. 8(1): p. 127.

15. Hwang, I.K., et al., Outcomes of treatment for malignant peripheral nerve sheath tumors: different clinical features associated with neurofibromatosis type 1. Cancer research and treatment: official journal of Korean Cancer Association, 2017. 49(3): p. 717.

16. LaFemina, J., et al., Oncologic outcomes of sporadic, neurofibromatosis-associated, and radiation-induced malignant peripheral nerve sheath tumors. Annals of surgical oncology, 2013. 20(1): p. 66-72.

17. Kolberg, M., Høland, M., Ågesen, T. H., Brekke, H. R., Liestøl, K., Hall, K. S., ... \& Lothe, R. A. (2012). Survival meta-analyses for> 1800 malignant peripheral nerve sheath tumor patients with and without neurofibromatosis type 1 . Neurooncology, 15(2), 135-147.

18. Güngör BŞ, Ekşioğlu MF, Atalay İB. Eklem İçi Yerleşim Gösteren Tümör ve Tümör Benzeri Oluşumların Cerrahi Tedavisinde Güncel Yaklaşımlar. Atik OŞ, editör. Eklem Hastalıkları Tedavisinde Güncel Yaklaşımlar. 1. Bask1. Ankara: Türkiye Klinikleri; 2019. p.80-5.

19. Atalay İB, Karakoç Y, Yılmaz S, Arıkan ŞM, Özanlağan E. Ekstremite yerleşimli intramüsküler hemanjiyomlarda takip mi? cerrahi mi? Acta Oncol \begin{tabular}{lll|l} 
Tur.. 2015; 48(3): 97-101 | DOI: & .
\end{tabular} 10.5505/aot.2015.84755

20. Öztürk R. Kemik ve yumuşak doku Tümörleri. In: Atay T, ed. Ortopedi ve spor Yaralanmaları Asistan Kitab1. Ankara, Derman Tibbi Yayıncılık; 2015:635e704.

https://doi.org/10.4328/DERMAN.3774. 